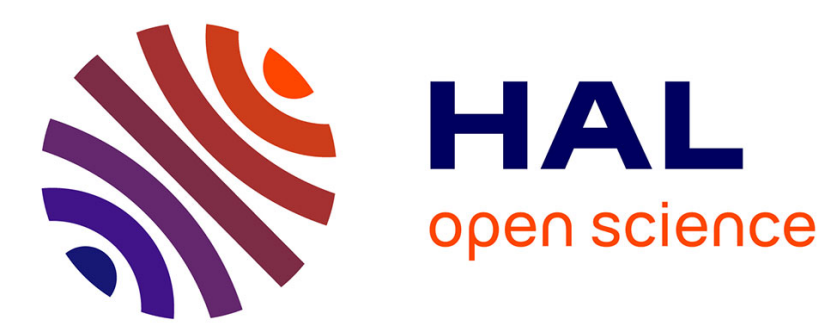

\title{
Twenty years of multi-level governance: 'Where Does It Come From? What Is It? Where Is It Going?'
}

\author{
Paul Stephenson
}

\section{To cite this version:}

Paul Stephenson. Twenty years of multi-level governance: 'Where Does It Come From? What Is It? Where Is It Going?'. Journal of European Public Policy, 2013, 20 (6), pp.817-837. 10.1080/13501763.2013.781818 . hal-01024837

\section{HAL Id: hal-01024837 \\ https://hal-sciencespo.archives-ouvertes.fr/hal-01024837}

Submitted on 16 Jul 2014

HAL is a multi-disciplinary open access archive for the deposit and dissemination of scientific research documents, whether they are published or not. The documents may come from teaching and research institutions in France or abroad, or from public or private research centers.
L'archive ouverte pluridisciplinaire HAL, est destinée au dépôt et à la diffusion de documents scientifiques de niveau recherche, publiés ou non, émanant des établissements d'enseignement et de recherche français ou étrangers, des laboratoires publics ou privés. 
This article was downloaded by: [FNSP Fondation National des Sciences Politiques]

On: 16 July 2014, At: 08:24

Publisher: Routledge

Informa Ltd Registered in England and Wales Registered Number: 1072954

Registered office: Mortimer House, 37-41 Mortimer Street, London W1T 3J H, UK

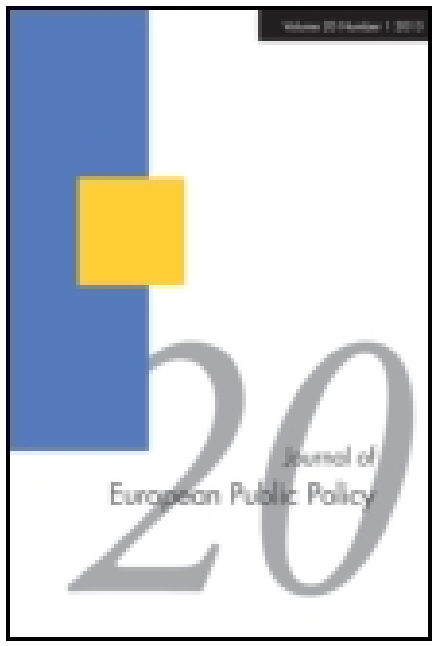

\section{J ournal of European Public Policy}

Publication details, including instructions for authors and subscription information:

http:/ / www. tandfonline.com/loi/ rjpp20

\section{Twenty years of multi-level governance: 'Where Does It Come From? What Is It? Where Is It Going?'}

Paul Stephenson

Published online: 29 May 2013.

To cite this article: Paul Stephenson (2013) Twenty years of multi-level governance: 'Where Does It Come From? What Is It? Where Is It Going?' , J ournal of European Public Policy, 20:6, 817-837, DOI: 10.1080/ 13501763.2013.781818

To link to this article: http:// dx.doi.org/ 10.1080/ 13501763.2013.781818

\section{PLEASE SCROLL DOWN FOR ARTICLE}

Taylor \& Francis makes every effort to ensure the accuracy of all the information (the "Content") contained in the publications on our platform. However, Taylor \& Francis, our agents, and our licensors make no representations or warranties whatsoever as to the accuracy, completeness, or suitability for any purpose of the Content. Any opinions and views expressed in this publication are the opinions and views of the authors, and are not the views of or endorsed by Taylor $\&$ Francis. The accuracy of the Content should not be relied upon and should be independently verified with primary sources of information. Taylor and Francis shall not be liable for any losses, actions, claims, proceedings, demands, costs, expenses, damages, and other liabilities whatsoever or howsoever caused arising directly or indirectly in connection with, in relation to or arising out of the use of the Content.

This article may be used for research, teaching, and private study purposes. Any substantial or systematic reproduction, redistribution, reselling, loan, sublicensing, systematic supply, or distribution in any form to anyone is expressly 
forbidden. Terms \& Conditions of access and use can be found at http:// www.tandfonline.com/page/terms-and-conditions 


\title{
Twenty years of multi-level governance: 'Where Does It Come From? What Is It? Where Is It Going?"
}

\author{
Paul Stephenson
}

\begin{abstract}
In two decades since the Maastricht Treaty, multi-level governance (MLG) has developed as a conceptual framework for profiling the 'arrangement' of policy-making activity performed within and across politico-administrative institutions located at different territorial levels. This contribution examines the ways in which the MLG literature has been employed, effectively taking stock of applied research to date. It identifies five main uses of MLG and the different focus of emerging research over time. Considering the most recent scholarship, the contribution explores possible new directions for research, in light of global governance, culminating in a 'bird's eye view' of MLG over 20 years.
\end{abstract}

KEY WORDS Cohesion policy; Europeanization; global governance; implementation; multi-level governance; policy networks.

\section{INTRODUCTION}

No other term in the study of European policy-making, perhaps in modern European political studies, has gained common currency like multi-level governance (MLG). As a concept it offers a palatable, easily digestible paradigm for grasping how the European Union (EU) works in practice. And yet, it has not been interpreted and applied in the same way by all scholars. Generally speaking, in face of both the issue complexity and institutional complexity of policy activity in the EU vis-à-vis national policy-making, MLG has been used to try to provide a simplified notion of what is pluralistic and highly dispersed policymaking activity, where multiple actors (individuals and institutions) participate, at various political levels, from the supranational to the sub-national or local. It implies spatial distinctions and geographical separation but, at the same time, its most vital feature is the linkages that connect levels. MLG implies engagement and influence - no level of activity being superior to the other - and, therein, a mutual dependency through the intertwining of policy-making activities.

To permit a sartorial analogy, MLG has been thrown around by scholars like a favourite coat - a staple item in the European political science wardrobe, but perhaps one worn so often that it has now become threadbare. Does it still do the job as it once did - covering the body (providing an explanatory 
framework), fulfilling the essential task of keeping out the draughts (accounting for the logic of institutional configurations)? This contribution explores the various uses of MLG and how they have changed over time. Given the wealth of academic output on, or relating to, MLG, the contribution discusses how it has been 'taken up' from various academic perspectives and concerns, with illustrative examples. In the latter part, it identifies areas where MLG may have further application for helping to overcome complexity and ambiguity in international policy-making.

Every scholar makes their own literature review, and no two lists are identical. The added value of this analytical review is its examination of how MLG has been embraced by a wide range of scholars and used in different ways over time, regardless of the original intentions of Gark Marks and Liesbet Hooghe, arguably the king and queen of multi-level governance. The selection of material is based on the novelty and significance of scholarship in terms of how it seeks to tackle institutional or issue complexity in the EU's multi-level system, but also how MLG has been reconciled with other sets of literature.

\section{MLG SINCE MAASTRICHT: WHERE DOES IT COME FROM? WHAT IS IT?}

In the 20 years since its first mention in an academic article (Marks 1993), the multi-level governance (MLG) literature has mushroomed. Its founders soon recognized competing visions of the concept (Marks and Hooghe 2004). MLG emerged as a vertical arrangement and a way to convey the intimate entanglement between the domestic and international levels of authority. It gave us a simplified way of understanding what European policy-making looked like on a day-to-day basis in (certain) policy areas, were we to slice the EU down the middle to obtain a cross-section of governance activity. Some derided MLG for its lack of predictive powers, asserting that it offered little explanation of causality, and, by consequence, classified it as a mere concept rather than a theory. This is arguably unfair because other prevalent frameworks (advocacy coalitions, policy networks, normative power) in policy analysis may have significant explanatory power to account for policy-making processes and actor/issue complexity, but do not necessarily aim at prediction either - even grand theory did not set out explicitly to peer into the future; rather neofunctionalism and intergovernmentalism evolved as lenses for interpreting the past. Thus, even if MLG could not provide a toolkit to help scholars explain the precise dynamics of how governance arrangements had come to be, what it could tell us was how governance was arranged today in a way that was easy to grasp, i.e., how the EU was performing as a 'polity' and 'machinery' (Kohler-Koch and Eising 1999: xii). In short, it overcame complexity.

The last five years has seen several 'retrospectives' of MLG. Conzelmann and Smith (2008) have taken stock and looked ahead, with a focus on structural funds and environmental policy. Piattoni (2009) has offered a historical 
and conceptual analysis that identifies the dichotomies of centre/periphery, state/society, domestic/international in multi-level governance, plotting them along three axes. Kohler-Koch and Larat (2009) have explored the diversity of research traditions in Europe and how MLG had been used in national research. Enderlein, Wälti and Zürn's (2010) 31-chapter edited 'handbook' has examined MLG from domestic and EU perspectives, but also regarding comparative regionalism and global governance. Bache and Andreou (2011) have uncovered nascent and emerging patterns of MLG across South-East Europe. Finally, Levi-Faur's (2012) recent 52-chapter volume, to which Bache (2012) also contributed, has examined MLG within the broader notion of governance, bringing in considerations of risk, regulation, markets and civil society.

While the 'first generation' of scholarship was caught up with the novelty of new governance forms and how they could transform basic institutional structures - perhaps in a rather introspective way - the 'second generation' of literature steered MLG towards new modes of governance and regulation (Conzelmann 2008: 26-7). To talk of generations is useful when attempting to group literature and draw out the main focus and applications. However, given the wealth of MLG literature after 20 years, it is now difficult to pinpoint precisely where one generation ends and another begins, particularly since some scholars may have used MLG for similar purposes over the entire period. Moreover, not all scholars are united in debate and exchange. Given the delays inherent in academic publishing, one should also be wary of fixing cut-off points. Instead, the most one can hope to do is identify when new uses of the literature first occur; any temporal dimension will be a 'loose sequence' of emergent scholarship. This second section examines four main uses of MLG, each with two focal points, while acknowledging the interconnectedness of themes and overlap in the literature.

\subsection{Original uses (1993-)}

\subsubsection{Legal jurisdictions of authority and efficiency}

Marks and Hooghe's (2004) original conceptualization of multi-level governance steered EU political studies away from the long-running theoretical ping-pong that fixated on proving the convincingness of intergovernmentalism or neofunctionalism to explain integration over 40 years. Three important events had just taken place. First, the reform of the Structural Funds in 1988 placed greater emphasis on partnership and co-ordination, bringing pressure to reform administrations and create rules and procedures for the shared management of structural funds. Second, the creation of the single market with the '1992' programme saw the mobilization and proliferation of interest groups within policy networks. Third, the signing of the Treaty on European Union in February 1992 spawned the concept of 'subsidiarity' or rather, the political desirability of policy action at the lowest possible level. 
Against this political backdrop, Mark's 1993 article entitled 'Structural Policy and Multi-Level Governance in the EC', analysed the then recent developments in the EC's 'structural policy', essentially asking two sets of questions: the first, 'How have institutional innovations come about, and which actors have been most responsible for shaping them?'; and the second set of three inter-related questions, 'What are the consequences of institutional innovation for existing institutions? What kind of political order is emerging in Europe? What are the consequences of institutional innovation for the existing state system?' Marks argued for the analysis of institution building to go beyond areas transparently dominated by the member states, i.e., financial decisions, major pieces of legislation and the treaties. Recognizing 'the increasing importance of subnational levels of decision-making and their myriad connections with other levels', he suggested the emergence of multi-level governance - 'a system of continuous negotiation among nested governments at several territorial tiers' as a result of 'a broad process of institutional creation and decisional reallocation that had pulled some previously centralized functions of the state' up and down (Marks 1993: 392).

This first article was soon followed by other scholars' explorations of MLG as an alternative to traditional state-centric forms of government (Marks et al. 1996), in light of its actor-centred (institutional) dimension (Marks 1996; Sharpf 1997a) and its obvious applicability to EU cohesion policy close-up (Hooghe 1996). MLG offered a conceptual framework (way of seeing) for studying European regional (cohesion) policy (Bache 1998; Benz and Eberlein 1999) and accounting for the broader transformation from 'government' to 'governance' and even 'metagovernance' (Bache and Flinders 2004; Jessop 2004; Kohler-Koch and Eising 1999). Together, Hooghe and Marks's (2001) consolidated volume encouraged a comparative investigation of institutional adaptation between the national and regional level (Börzel 2002), and the supranational and national level (Kohler-Koch 2003). In a nutshell, MLG captured the state's own 'unravelling', i.e., it was no longer tightly centralized and/or performing all functions at the highest level; like a coat whose thread had got caught, its main body being pulled apart.

Hooghe and Marks (2003: 234) recognized the inadequacy of political science responses to what was occurring, with the stretching of 'established concepts over the new phenomena'. Whereas federalists sought to explain developments in power-sharing among and within states, International Relations (IR) scholars extended theories of international regimes to account for the 'diffusion of authority within states'. How to explain that more flexible arrangements were emerging - was it a question of rational choice on the grounds that governance could be more efficient by varying the territorial scale and degree of centralization? The authors distinguished between: general purpose jurisdictions with non-intersecting (static) memberships at a limited number of levels (often rather rigid in their terms of institutional architecture); and task-specific jurisdictions of intersecting (fluid) membership with unlimited levels and flexible in design. Type 1 was like a 'Russian doll set' 
with only one relevant jurisdiction/authority at each level, whereas type 2 was a puzzle made up of many functionally specific pieces, each providing services or solving problems. The first reflected the simplistic nature of state control and the exertion of authority in a unitary state, while the second expressed the layered system of co-existing levels of authority - a complex pattern of transnational, public and private institutional relations with overlapping competences (Hooghe and Marks 2003: 235-6).

\subsubsection{Europeanization and regionalization}

There is an overlap with MLG and the literature on regionalization and Europeanization, particularly since MLG was originally studied with a view to the functional pressures to regionalize in order to accommodate policy, i.e., to create mechanisms enabling the access to, and active participation of regional interests in, the policy process. Three solutions to 'the dilemma of exclusion and inclusion' for multi-level actors were: hierarchical sequencing, flexible association/disassociation and loose coupling. As Benz and Eberlein (1999: 329) assert, empirical studies of subnational political action helped advance MLG, following the build-up of the (then) European Community's regional level engagement in the policy process. MLG emphasized power-sharing and the dispersion rather than accumulation of authority, while Europeanization brought new patterns of inter-organizational linkages and saw the dynamics of mutual adjustments (patterns of adaptation) made by institutions as a result of multilevel interactions (Jordan 2001). The challenges for domestic structures to secure political representation and co-ordination included overcoming horizontal divisions and conflicts between/within regional politico-administrative bodies, and repairing distant and/or distrustful vertical relations between national and supranational levels.

It is no coincidence that much of the literature emerging at this time from regional studies scholars (Keating and Loughlin 1997) and on interest representation (Greenwood 2003) tied into MLG debates, at a time when hundreds of regions were establishing a physical presence in Brussels through their own offices. This phenomenon challenged established state-centric assumptions of international relations, sparking greater interest in 'intermediate level innovation', while MLG 'assumed the meaning of a conceptual umbrella'. The 'impressive extension' of the multi-level governance framework allowed it to be used to interpret and explain Europeanization processes, with the result that scholars 'devoted' greater attention 'to the diverse, contradictory and anything but linear trajectories of institutional change and institutionalization' (Gualini 2003: 418). With more complex and varied electoral arenas, political parties needed new strategies to perform effectively in 'multi-layered systems'; however, MLG was 'very much a party-free zone' (Deschouwer 2003: 213; see also Hepburn 2008). In short, MLG was about opportunities for some and loss (of power and influence) for others, leading to potential conflict, blocking and, subsequently, strategies to circumvent the national level whereby lower levels sought to increase their institutional and negotiating capacity. 
Building on earlier work, where he termed the phrase 'flexible gatekeeping', Bache (1998) reconciled MLG with Europeanization in a study of cohesion policy in the United Kingdom (UK) and the EU. He noted the rise in flexible type 2 arrangements ('loose neocorporatism') across local governance in the 1990 s with the 'revival' of English regions. However, one could not assume causality between MLG pressures from Brussels and the process of devolution, which had long been part of the UK's domestic political agenda (Bache 2008: 156). The author criticized MLG for failing to distinguish between governance and participation (or dialogue); what was missing from the debate were empirical indicators. If governance implied engagement, how could one measure the exertion of influence, and gauge the outcomes of participation in decision-making processes when power relations were ill-defined and with so little insight into the links between actors? Bache (2008: 162) saw policy networks as an obvious bridge between MLG and Europeanization. Warleigh-Lack (2008) later advocated combining MLG with policy networks, the complexity and plurality of networks in MLG implying a 'push and pull' between institutions.

\subsection{Functional uses (1997-)}

\subsubsection{Policy/country studies and implementation studies}

From the outset, MLG was used extensively to analyse institutional arrangements for the implementation of structural funds in cohesion policy, uncovering diverging formal and informal rules at the national and supranational level to explain multi-level tensions. So successful was MLG that it soon entered into the language of policy-makers. The Committee of the Regions today organizes annual 'ateliers' to bring together scholars and practitioners to celebrate - and in so doing legitimize - multi-level governance. It considers MLG to mean coordinated action by the supranational institutions with national, regional and local authorities, based on partnership and aimed at drawing up and implementing EU policies (Warleigh 1999). The focus on co-ordination and partnership at various stages of the policy-making process, including (re-)formulation and implementation, implies pluralistic interactions, different institutional levels coming together to 'govern', be it in a functional and administrative capacity.

Through several rounds of enlargement, academic analyses of MLG shifted from the old to new member states in Eastern and South-East Europe. Yet, country case studies showed the persistence of central control in the face of diverging subnational practices. Regionalization processes triggered differentiation, resulting in very varied administrative governmental capacities across multiple arenas (Benz and Eberlein 1999; Milio 2010; Piattoni 2008; Stubbs 2005; Taylor et al. 2012; Thielemann 1999). MLG was applied extensively in environmental policy (Fairbrass and Jordan 2004; Knill and Tosun 2008), but also in other 'first pillar areas' such as telecoms policy (Fuchs 1994), food safety (Bernauer and Caduff 2004) and innovation policy/leadership (Kaiser and Prange 2004). Attempts were even made to apply it to international relations (Welch and Kennedy-Pipe 2004), economic policy (Perraton and 
Wells 2004), demand and supply (Rosenau 2004), international trade policy (Knodt 2004), common foreign security policy (Smith 2004) and climate change governance (Kern and Bulkely 2009). In short, there is a clear overlap here with the original focus on regionalization, or, rather, the administrative process and consequences of implementing EU policy.

\subsubsection{Problem-solving, co-ordination, learning}

In MLG's relative infancy, Scharpf (1997b) explored its problem-solving capacity, arguing that its effectiveness at different governance levels varied from one policy area to the other. He identified constraints on both national and European capacity in a range of policy domains, offering a two-dimensional conceptualization of multi-level problem-solving capacities - a move away from bargaining towards positive-sum games. Scholars observed a shift from national policy control to European level co-ordination - in transport, telecoms and energy infrastructures. Exploring the impacts of non-regulatory policies at the member state level, Conzelmann (1998) examined the changing context of regional policy, noting how multi-level consensus on policy solutions reduced conflict.

Scholars examined learning in the context of MLG (Paraskevopoulos 2001). Schout (2009) focused on variations across governance level, policy instrument and organization type, questioning how instruments were designed and used in the EU's multi-level system. Had the so-called 'governance turn' delivered on its promises of enabling better problem-solving? To answer these questions, one needed to consider the sociological aspects of MLG - structures, processes and procedures - as well as leadership. Egan (2009: 1248) noted how, because of the growth of transnational networks, policy learning was taking place in multiple venues; co-operation and interaction was fostering the exchange of ideas, technical expertise and information, as well as the promotion of norms and values. He referred to cross-national networks of collaboration at the international level that were emulating, copying, borrowing and imitating their neighbours. Indeed, MLG encouraged experimentation, to overcome political and financial 'stalemates' through exposure to ideas from outside that could transform the understanding of self-interest (Zito and Schout 2009: 1115). With MLG now reconciled with 'networked governance' (Jordan and Schout 2006), policy-making was considered a process involving self-organizing, multi-level actors - and one which signalled a move away from 'hierarchical steering' towards communication-based instruments.

\subsection{Combined uses (2001-)}

\subsubsection{New modes of governance}

One might argue that the open method of co-ordination (OMC) introduced at Lisbon in 2000 was MLG's first serious contender as a rival governance framework. This new approach saw the EU as 'heterarchical' and 'decentred', with OMC 'radicalizing' the process of subisidarity (Hodson and Maher 2001: 719). 
'Soft' policy instruments not backed by EU legislation encouraged co-ordination, benchmarking and best practice without any threat of sanctions. Yet, Kaiser and Prange (2004) found the multi-level governance character of innovation policies a major stumbling block to applying OMC - in fact vertical policy co-ordination and horizontal policy learning could not occur. MLG enabled non-hierarchical linkages for interdependent policy co-ordination, but it appeared scholars had underestimated the conditions needed to ensure effective policy co-ordination and, hence, convergence, such were the massive variations among member states and regions in terms of budgetary powers and legal competencies. The authors identified vertical co-ordination problems including increasing transaction costs, which rose with 'the number of administrative levels and degree of subnational autonomy' (ibid.: 250).

Beyond social and employment policy, which were trialling OMC, private organizations as well as public bodies were becoming important actors. Multi-level actors were competing heavily for critical resources (knowledge, research, finance, entrepreneurs, etc.), but there was a mismatch or 'tension' between political ambitions and market reality. It was uncertain if one could achieve critical mass with such dispersed authority. How would long-established innovation policies at the level of the German Länder react to top-down policies cooked up in Brussels? (ibid.: 255-7).

OMC had promoted transparency via data exchange, benchmarking and best practice both vertically between governance layers, and horizontally across 27 member states. One could thus conceive of the EU as a 'multi-level information environment' in which communication and data processing were determined by dimensions of complexity (density, structurability, heterogeneity), as explored by Blom et al. (2008). MLG empowered subnational actors by bringing them into decision-making arenas, and giving them greater access to information, i.e., knowledge: 'informal and disorderly governance relates to and overlays orderly and formal governance' (Bache 2008: 163). Héritier and Rhodes (2011) have asked how and where informal governance sits in MLG's tightly coupled institutional construct 'in the shadow of hierarchy'. Defining governance as a specific mode of production of norms and public goods created via co-production, where the co-producers transcend different levels, the authors recognized the growing importance of public-private decision networks involving many types of public authority.

\subsubsection{New institutionalism/principal-agent theory}

In Schmitter's (2004) scheme of regional integration 'multi-level and polycentric governance' sits at the centre of a box containing six types of institutionalism (rational, historical, epistemic, legal, political and sociological). MLG is here defined as:

an arrangement for making binding decisions which engages a multiplicity of politically independent but otherwise interdependent actors - private and public - are at different levels of territorial aggregation in more-or-less 
continuous negotiation/deliberation/implementation, and that does not assign exclusive policy compétence or assert a stable hierarchy of political authority to any of these levels. (Schmitter and Kim 2005: 5)

Schmitter stressed the spatial (polycentric nature of the EU), pluralistic (no single collective institution) and functional dimensions (delegated tasks). MLG's popularity was supposedly owing to its descriptive neutrality and thus, 'putative compatibility with virtually any of the institutional theories and even several of their more extreme predecessors', i.e., its strength was its malleability and impartiality, while its limitation was its explanatory power and insight. For politicians, Schmitter and Kim (2005: 5) conceded, it also avoids the controversial word 'state' and 'sounds a lot less forbidding and threatening'.

Blom-Hansen (2005: 644) used principal-agent theory (found in rational choice institutionalism) to break MLG's 'virtual monopoly' on analysing cohesion policy. He conceded that while this MLG 'paints a descriptively accurate picture of the cohesion policy's complex implementation structure, it fails to specify which actors, at which levels, will be causally important'. A principal-agent framework helped focus on control mechanisms and potential implementation deficits (ibid.: 625). Moreover, MLG was criticized for equating multi-level involvement (in decision-making) with multi-level governance, and failing to specify why certain levels are empowered and others weakened. Acknowledging that 'cohesion policy involves a chain of principal-agent relationships, ranging from the European Council to local authorities', he advocated more studies to reveal domestic institutional relationships, rather than focusing on the supranational level. More specifically, how did rules and resources influence control, and determine the dynamics of MLG? (ibid: 629-30).

Acknowledging MLG as a 'reconfiguration of policy-making space in the EU', and perceiving of institutions as 'honey pot sites', Awesti (2007: 1) proposed a framework for understanding MLG from three institutional perspectives, to 'test' MLG. First, he asserted that from the conceptual lens of rational choice institutionalism ( $R C I$ ), polycentric governance emerges out of explicit choices made by national leaders in view of perceived functional benefits, and noted how Marks (1996: 28) himself had hypothesized that authority may be reallocated if it is seen to have 'politically salient pareto beneficial consequences' such as 'reduc[ing] transaction costs or increas[ing] the efficiency of policy provision' (Awesti 2007: 11-12). Second, path dependency is present in MLG since institutional structures and processes become difficult to modify. From an historical institutionalist perspective (Pierson 1996), MLG arrangements get 'locked-in' as a permanent feature of the EU policy system, as actors adapt socially to procedures and norms, while the cost of exit gradually increases; governance arrangement becomes 'sticky' (Awesti 2007: 13-17). In cohesion policy, the norm of 'generalized reciprocity' based on exchange and mutual expectations, persists over time, transforming zero-sum relations 
(Paraskevopoulos 2001: 260). Third, from a sociological institutionalist perspective, actor behaviour in MLG is practised, experienced and replicated: subnational actors in turn exert pressure that favours the further dispersal of authority away from the centre; MLG becomes self-reinforcing as actors, such as policy officers and decision-makers, learn to function according to the behavioural rules of MLG, which encourages highly dense and frequent interaction. Arguably, MLG has itself become a normative feature or value of the EU (Awesti 2007: 17-19). That said, legalistic traditions, deeply entrenched institutional rules and norms at different levels can still obstruct new domestic-supranational relations (Thielemann 1999: 402).

\subsection{Normative uses (2003-)}

\subsubsection{Legitimacy, democracy, accountability}

The White Paper on European Governance (Commission 2001) contained recommendations to enhance democracy and increase the legitimacy of the institutions in the wake of the dissolution of the Santer Commission. Soon after, Olsson (2003) examined 'paradoxes' of MLG in the system of EU structural funds implementation, from a democracy perspective, to see how the burgeoning literature on democracy renewal could be reconciled with MLG. The issue was 'often unproblematized' - if democracy was discussed, it was regarding the basic character of the EU (or perhaps applied to the European Parliament), rather than power and policy-making processes (Olsson 2003: 284). The author saw MLG as essentially top-down and technocratic, but with democratic institutions marginalized; 'democratizing' MLG would mean regulating partnerships or challenging the partnership principle introduced in 1998 with the parliamentary principle, to give policy implementation more democratic legitimacy.

Peters and Pierre (2004) saw MLG as compromising democracy and called it a 'Faustian bargain' - had policy-making sold its soul? Harlow and Rawlings (2006) recognized an 'accountability deficit' in MLG which had itself become organized around self-organizing, self-regulating networks. With governance essentially about co-operation and co-ordination, traditional government control systems were 'undermined'. In fact, not more than 17 per cent of the 1,600 projects in the Connex database on EU governance addressed democracy (Kohler-Koch 2006). Papadopoulos (2008) criticized the scholarly focus in MLG research on managerial concerns of performance and efficiency. Increasing networks in MLG meant governance was 'uncoupled' from the democratic circuit owing to its weak visibility, poor presence of citizen representatives and prevalence of 'peer review' (which relates to the earlier discussion of OMC). MLG 'inhibited' accountability, which required democratic (political) control as well as administrative, fiscal and legal control (Papadopoulos 2008: 40); the fragmentation of power resources between levels meant technocrats were not really politically accountable.

Heinelt (2008) argued that political science reflections should not concern the achievement (or not) of policy objectives - which may be sufficient for applied 
policy studies or efficiency-oriented analyses of inputs and outputs - but rather the basic political logic of governing public affairs in the multi-layered spheres of EU politics' (Heinelt 2008: 54). Acknowledging the institutional complexity of MLG, and the 'context-related choices faced by groups of actors so that they can influence purposefully and act interactively', he advocated research to address actor-related capabilities by examining the social environment, available policy instruments and existing institutional settings; one needed to examine MLG endogenously to see what politically determined opportunities and constraints in policy-making, including the 'varying desires, knowledge and perceptions of the multitude of involved actors' who distribute the various tasks and competences between different nested levels (Heinelt 2008: 54-6).

\subsubsection{Identity politics (community, collective identities, political parties, public sphere)}

Finally, it is perhaps fitting that the last of the eight focal points on MLG literature brings us back to Hooghe and Marks (2008), who, in recent work, have explored the possibility of a 'postfunctionalist theory of European integration' - acknowledging an inclement political climate where things have gone 'from permissive consensus to constraining dissensus'. They refer - as they did at the outset to the articulation of authority across 'jurisdictions' or the 'jurisdictional architecture', and take up the 'building blocks' of multi-level governance, while seeking to reduce complexity and direct attention to one particularly important causallypowerful factor: identity. The duo asserts that, while governance concerns the efficient delivery of collective benefits, it is also an expression of community. Give its functional rationale, MLG should better acknowledge how the optimal human co-ordination of resources and tasks does not necessarily coincide with the territorial scope of community - 'doing' European integration means mobilizing identity, particularly where existing regional political structures of authority are inappropriate, be it inefficient or unconvincing/conflicting. The authors explicitly acknowledge citizens and identity in their definition of governance as 'binding decision making in the public sphere' (Hooghe and Marks 2008: 2), while recognizing that the political experience of MLG - and the research it generated - dismantled many of the original assumptions: first, that public attitudes were superficial and irrelevant; second, that integration was an issue of low salience for the public; and third, that issues emerging from integration were unrelated to basic political conflict between parties, institutions and regions. In short, the $\mathrm{EU}$ is system of MLG 'driven by identity politics as well as functional and distributional pressures' given that 'community and self-governance, expressed in public opinion and mobilized by political parties, lie at the heart of jurisdictional design' (Hooghe and Marks 2008: 23).

\subsection{MLG so far: summing up}

The legal and economic ideas providing the rationale for multi-level governance meant that the academic literature was taken up widely in public administration 
and policy analysis. Political science theories have since been brought in tandem with MLG, to see how they might inform each other, while a more critical literature has been preoccupied with certain social and political philosophical concerns over MLG.

Thus, MLG captured, and simplified, the spatial configurations of policymaking activity, not just decision-making. This implied the dispersal and redistribution of powers and competences to different levels of policymaking activity, and roles for both existing and newly-created institutions and bodies, i.e., of interconnected public and private actors. Acknowledging the emergence of policy communities and issue networks in the EU, calls were made for MLG to be reconciled with the literature on policy networks (Warleigh-Lack 2008). Conceptually, networks were supposed to be nonhierarchical, but in reality, only some enjoyed agenda-setting and decisionmaking powers; others were merely active in implementation. The complexity and plurality of networks in MLG implied a certain 'push and pull' between institutions; but while MLG was lauded as promoting participation, and sustaining the momentum for ongoing co-operation and consensus, it invariably led to conflict and resistance. Indeed, MLG destabilized, fragmented and restructured existing organizational patterns, challenging the existing concentration of power/authority with the opportunities and threats it represents. It also altered political culture and organizational behaviour, bringing new values to policy-making.

From a normative point of view, MLG has burgeoned on the premise of functional efficiency, accountability and democratic legitimacy. Indeed, the functional requirements of implementing many policies have demanded massive politico-administrative reorganization at lower levels, and hence the Europeanization - and to a degree harmonization - of spaces and their units of control. MLG has led to varying degrees of centralization and decentralization. Newly organized territorial structures have bolstered MLG, but in some cases changes in domestic structures cannot always be explained by the EU but by internal pressures for change - as such we must not discount the role of identity in enabling MLG. While MLG has been used widely for the analysis of policymaking in former first pillar areas that are institutionally complex, it cannot wholly account for - and is not particularly representative of - policymaking activity in more complex (high politics) issue areas, such as foreign policy or trade and development, where subnational levels have fewer competences.

Finally, while MLG emerged in the literature to account for transformation in the distribution of authority on grounds of efficiency, and with a functional logic (as would support argument within rational choice institutionalism), subsequent literature adopted a more sociological focus, examining organizational and social learning, and identity/community, making bridges with both the public policy literature in the field that was evolving in parallel in the 1990s, as well as the earlier seminal work on functionalism/neofunctionalism - indeed, after 15 years, the focus on learning takes 
us almost full circle to the role of élites in institutionalism, their desires and norms.

\section{CURRENT AND FUTURE MLG SCHOLARSHIP: WHERE IS IT GOING?}

MLG began by analysing arrangements for implementing the structural funds. Today most major recipients are flailing in the wake of the global financial and euro crises. This has brought home how the EU's fate is intrinsically linked to international politics and economics. MLG no longer operates in splendid isolation as a three-layered, Eurocentric, isolated vision of policy-making, but acknowledges external actors in global governance (GG). The most recent scholarship, in the last five years, has examined transformations from a comparative perspective at the macro and micro level. This section thus introduces a fifth use of the literature around two additional focal points.

\subsection{Comparative uses (2007-)}

\subsubsection{Global governance and international institutions}

MLG is being used in the context of globalization and development, international law, finance and trade, exploring its relevance and application outside Europe. Almost a decade ago, Knodt (2004) sought to 'emancipate' MLG from its structural policy origins, to better consider the international context. Analysing the World Trade Organization, she examined how the EU's international embeddedness influenced its own institutional change and the formal organization of European decision-making. Recently scholars have adopted a more concerted international outlook (Enderlein 2010). This seems logical when so many policy issues are transnational, and require solutions from the international community through global governance mechanisms. Kaul (2010: 323) has provided lessons for MLG by analysing the changing role of the United Nations (UN) as it struggles to adapt to a new world order where states act 'as intermediaries between national interests and global policy demands'. Slaughter and Hale (2010: 358-9; emphasis added) recognize that what distinguishes MLG's functional, autonomous units from 'mere issue networks' is 'a certain durability of the arrangement and process' - while transgovernmental networks in the EU may be vertical, 'the real world' (i.e., international policy-making today) is characterized by both vertical and horizontal arrangements in what the authors call, a 'governance matrix'. Beisheim, Campe and Schäferhoff (2010: 370) have revisited transnational publicprivate partnerships (PPPs), and consider them a type 2 form of MLG governance, 'whereby non-state actors co-govern along with state actors for the provision of collective goods and adopt governance functions that have formerly been the sole authority of sovereign states'. Such PPPs are found in global alliances and project partnerships initiated by the UN Development Programme and World Bank for water management and planning. The authors explore 
PPPs' 'virtues and deficits', identifying conditions under which they can be effective and legitimate MLG instruments.

Economic policy-making, not traditionally a first pillar policy, is now 'almost by definition' an area of multi-level governance, according to Enderlein (2010: 423-4). Offering three examples - fiscal federalism (subnational and national level), Economic and Monetary Union in Europe (regional level) and international monetary co-operation and global economic governance (supranational) - he asks if economic policy-making could and should be considered as a single MLG system, or whether one can really treat them as analytically separate' (emphasis added). Arguably, we can't. Spendzharova (2011), in her examination of the multi-level dimension of the European financial crisis, discusses international financial institutions in the same breath as domestic financial sectors, alongside euroscepticism and civil society at the subnational level. She pinpoints the tension between greater centralization of authority at higher levels of governance versus regulatory autonomy at lower levels.

So is multi-level governance now the same as global governance (GG)? Is there simply now a fourth or fifth politico-administrative or technocratic level? Zürn (2012) thinks not. For GG to be multi-level, two conditions must be met: first, the global level must possess authority of its own, beyond mere intergovernmental co-ordination, and with a delegation of powers; second, there should be interplay within the system that demonstrates a division of labour across the levels. Nonetheless, GG can be prescribed as a specific form of MLG when global institutions possess and exert political authority.

\subsubsection{EU \& regionalism}

Scholars have been using MLG to make comparative analyses of other regions, using the EU as the yardstick. De Prado (2007: 215) had conceived of global MLG when comparing trends in the EU with those in Asia, but argued that a gradual transformation towards a new world order should be theorized by a 'knowledge-based global multi-level governance paradigm', recognizing that a 'knowledge revolution catalysed by information and communications technologies' will give rise to more transnational actors and regional processes, all influencing governance at various inter-related levels. For Sbragia (2010: 268), the concept of MLG is 'especially tricky' when examined outside of the EU. The dynamics of MLG are very different in the North American Free Trade Agreement (NAFTA), given the 'ironclad commitment to avoid institutionalization and institution-building'. Mercosur is not even a free trade area though highly 'inter-presidential', dependent on personal intervention. Its largest states - Brazil and Argentina - are highly decentralized, a de facto limitation to any extensive arrangement of governance functions vertically. As for the 'developing world', scholarly research is too underdeveloped to make any serious evaluation of MLG (Sbragia 2010: 269); the most obvious comparison is the Associations of Southeast Asian Nations (ASEAN), which bears few institutional similarities to the EU, relying heavily on norm diffusion and developing consensus to promote change and integration (Schreurs 2010). Meanwhile, 
Obydenkova (2010) claims regionalism in post-Soviet Eurasia represents a form of MLG because it includes different institutional layers (supranational and trans-subnational) and groups of actors (governmental and non-governmental). Where vertical integration has failed, horizontal integration has been successful: the Commonwealth of Independent States is unique in that sovereignty and independence among states has not been the starting point, nor has economic integration. Can MLG help explain why there has been little progress in over two decades, despite the 'undeniable advantages of integration' (ibid.: 293)?

\subsubsection{Looking ahead: administrative processes, tasks and interactions}

Finally, MLG scholarship long hovered above multi-level institutions, treating each institutional actor as a unitary body. Further scholarship might examine actors inside institutions to see how individual and collective identities are asserted, forged and transformed through functional processes of problemsolving and task distribution. Indeed, focussing on the earlier stages of policy-making rather than implementation would suggest an approximation with the agenda-setting literature on images and venues (Baumgartner and Jones 1993). Scholars have called for more attention to be paid to mapping administrative interactions throughout the policy process, and identifying what practical types of decision-making are involved. Littoz-Monnet (2010), in her exploration of the notion of 'dynamic multi-level governance', proposes a model called 'reversed intergovernmentalism' that would better account for how actions between venues at multiple levels - including the international - actually lead to decisions, rather than analysing what happens next (ibid.: 4).

Heidbreder (2011) acknowledges the persistent differences between 27 increasingly interdependent national systems. She calls for a more comprehensive understanding of the EU as a 'multi-level public administration', to better distinguish policy-making procedures; her typology of 'supranational instrumentation' differentiates between explicit versus implicit supranational rule (ibid: 710). One might bring in role theory (Biddle 1986) to reinforce actorcentred analyses of multi-level public administrations, such as recently applied in EU foreign policy (Juncos and Pomorska 2010). Since MLG implies a variety of tasks depending on the configuration of actors at particular points in policy-making time and space, we might consider more practically oriented, interactions-based perspectives of MLG that shed light on the specifics of task-based activities, to illustrate more comprehensively the when, where and what of governance. Heinelt and Lang's (2011) empirical study already improves our understanding of MLG in practice by comparing regional actor constellations across different phases of EU cohesion policy. Focusing on operational programmes, the authors account for variations in governance arrangements in cohesion, non-cohesion and Central and Eastern European (CEE) countries. In short, further research might dig deeper still into the functional aspects of 'doing policy', adopting more sociological considerations and acknowledging ontological questions, including the different ways actors 


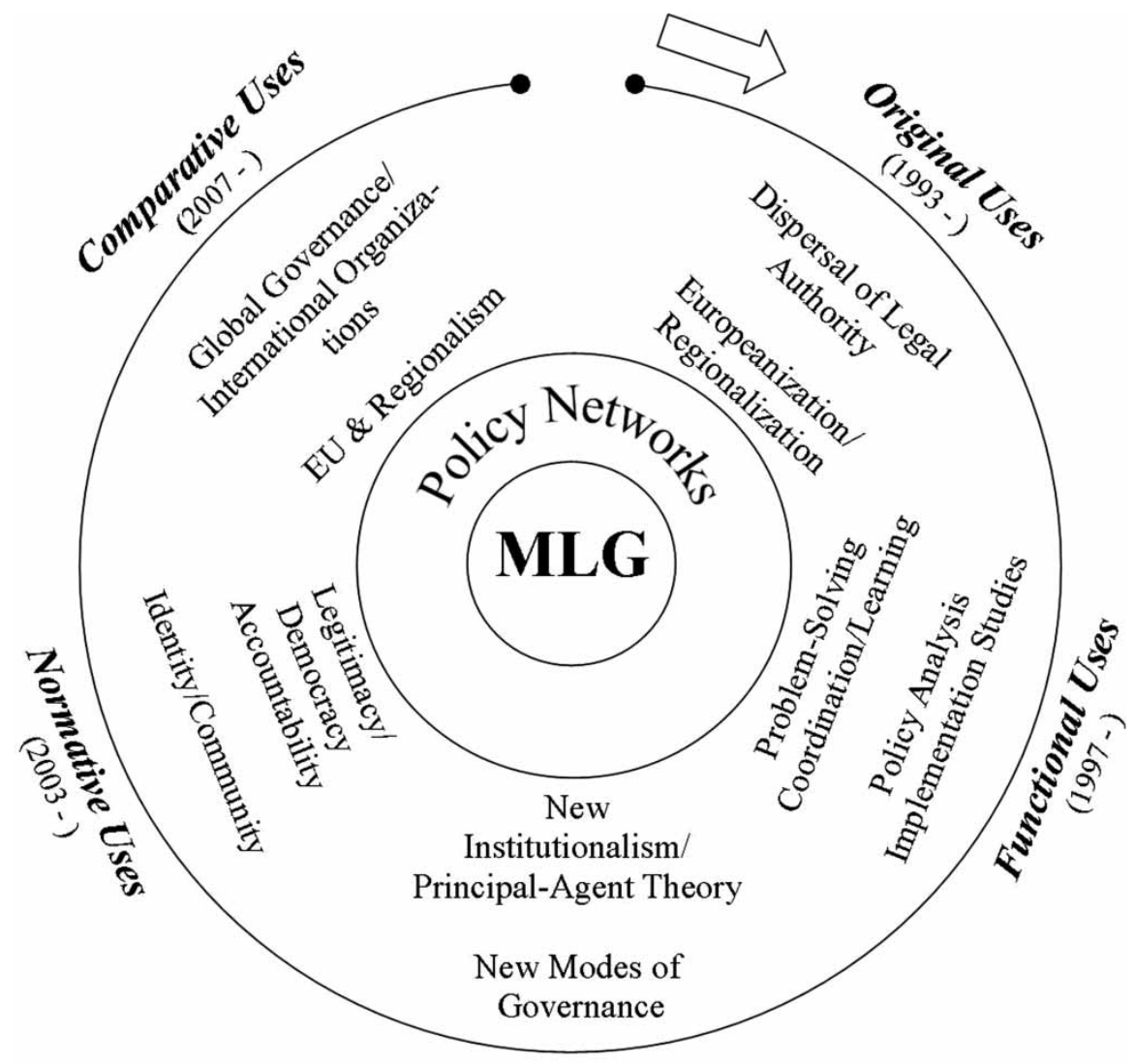

\section{Combined Uses}

(2001 - )

Figure 1 A bird's eye view of MLG's uses over two decades

engaged in multi-level interactions actually see the EU and their place within it, as well as examining close-up institutional actors' tasks across policy domains throughout the stages of the policy cycle.

Figure 1 offers a visual representation of MLG scholarship, in which the five 'uses' and 10 'focal points' have been loosely sequenced, distinguishing between original, functional, combined, normative and comparative uses of the MLG literature. The bird's eye view of multi-level governance captures the evolution in scholarship over time.

\section{CONCLUSION}

The landscape of European governance has been transformed in two decades. The original concept of MLG has been used by scholars in diverse ways. 
The increasing issue and institutional complexity of EU policy-making activity can no longer be captured through an isolated, three-layered conceptualization. Scholars are beginning to analyse the interdependence of the EU with global institutions and governance. There is a need to hone in, through more applied research, to the incremental and pluralistic nature of MLG, to consider the degree to which issue complexity may determine or shape institutional arrangements. This may mean appropriating the existing literature with international relations, or else with sociology and public administration, in order to better grasp institutional/actor complexity. MLG as a conceptual garment of European political science may need 'accessorizing', or to be worn inside out, to provide a new look - one that maintains its relevance and usefulness for this season's policy analysis, wherever the EU is going.

Biographical note: Paul Stephenson is Assistant Professor at the Department of Political Science, Maastricht University.

Address for correspondence: Paul J. Stephenson, Department of Political Science, Faculty of Arts and Social Sciences, Maastricht University, PO Box 616, 6200 MD Maastricht, The Netherlands. email: p.stephenson@ maastrichtuniversity.nl

\section{ACKNOWLEDGEMENTS}

I wish to thank Nikolaos Zahariadis and the anonymous reviewers for their helpful comments on early drafts. I am particularly grateful to Tod Hartman for his help turning my original pencil sketch into Figure 1.

\section{NOTE}

*After 'Where Do We Come From? What Are We? Where Are We Going?', Paul Gauguin's most famous painting; the expression of a highly individualistic mythology and the culmination of his thoughts $(1897 / 8)$.

\section{REFERENCES}

Awesti, A. (2007) 'The European Union, New institutionalism and types of multi-level governance', Political Perspectives EPRU 2(8): 1-23.

Bache, I. (1998) Politics of European Union Regional Policy: Multi-level Governance or Flexible Gatekeeping? Sheffield: Continuum.

Bache, I. (2008) Europeanization and Multilevel Governance: Cohesion Policy in the European Union and Britain, Lanham, MD: Rowman and Littlefield.

Bache, I. (2012) 'Multi-level governance in the European Union', in D. Levi-Faur (ed.), Oxford Handbook of Governance, Oxford: Oxford University Press, pp. 628-41.

Bache, I. and Andreou, G. (eds) (2011) Cohesion Policy and Multi-level Governance in South East Europe, Oxford: Routledge.

Bache, I. and Flinders, M. (eds) (2004) Multi-level Governance, Oxford: Oxford University Press. 
Baumgartner, F. and Jones, B. (1993) Agendas and Instability in American Politics, Chicago, IL: University of Chicago Press.

Beisheim, M., Campe, S. and Schäferhoff, M. (2010) 'Global governance through public-private partnerships', in H. Enderlein, S. Wälti and M. Zürn (eds), Handbook on Multi-level Governance, Cheltenham: Edward Elgar, pp. 370-82.

Benz, A. and Eberlein, B. (1999) 'The Europeanization of regional policies: patterns of multi-level governance', Journal of European Public Policy 6(2): 329-48.

Bernauer, D. and Caduff, C. (2004) 'European food safety: multi-level governance, re-nationalization or centralization?' CIS Working Paper, available at http://www.cis.ethz.ch/ publications/publications/WP3_Bernauer_Caduff.pdf (accessed 20 October 2011).

Biddle, B. (1986) 'Recent developments in role theory', Annual Review of Sociology 12: 67-92.

Blom-Hansen, J. (2005) 'Principals, agents, and the implementation of EU cohesion policy', Journal of European Public Policy 12(4): 624-48.

Blom, T., Radulova, E. and Arnold, C. (2008) 'Theorizing modes of governance in the EU: institutional design and informational complexity', European Governance Papers/Eurogov, 1-34.

Börzel, T. (2002) States and Regions in the European Union: Institutional Adaptation in Germany and Spain, Oxford: Oxford University Press.

Commission of the European Communities (2001) 'European governance. A white

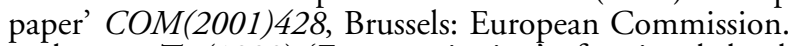

Conzelmann, T. (1998) 'Europeanisation' of regional development policies? Linking the multi-level governance approach with theories of policy learning and policy change', EIoP 2(4), available at http://eiop.or.at/eiop/texte/1998-004a.htm (accessed 10 October 2011).

Conzelmann, T. (2008) 'A new mode of governing? Multi-level governance between cooperation and conflict', in T. Conzelmann and R. Smith (eds), Multi-level Governance in the European Union: Taking Stock and Looking Ahead, Baden Baden: Nomos, pp. 11-30.

Conzelmann, T. and Smith, R. (eds) (2008) Multi-level Governance in the European Union: Taking Stock and Looking Ahead, Baden Baden: Nomos.

De Prado, C. (2007) Global Multi-level Governance: European and East Asian Leadership, Tokyo: United Nations University Press.

Deschouwer, K. (2003) 'Political parties in multi-layered systems', European Urban and Regional Studies 10(3): 213-26.

Egan, M. (2009) 'Governance and learning in the post-Maastricht era?', Journal of European Public Policy 16(8): 1244-53.

Enderlein, H. (2010) 'Economic policy-making and multi-level governance', in H. Enderlein, S. Wälti and M. Zürn (eds), Handbook on Multi-level Governance, Cheltenham: Edward Elgar, pp. 423-40.

Enderlein, H., Wälti, S. and Zürn, M. (2010) Handbook on Multi-level Governance, Cheltenham: Edward Elgar.

Fairbrass, J. and Jordan, A. (2004) 'Multi-level governance and environmental policy', in I. Bache and M. Flinders (eds), Multi-level Governance, Oxford: Oxford University Press, pp. 147-64.

Fuchs, G. (1994) 'Policy-making in a system of multi-level governance - the Commission of the European Community and the restructuring of the telecommunications sector', Journal of European Public Policy 1(2): 177-94.

Greenwood, J. (2003) Interest Representation in the European Union, Basingstoke: Palgrave Macmillan.

Gualini, E. (2003) 'Challenges to multi-level governance: contradictions and conflicts in the Europeanization of Italian regional policy', Journal of European Public Policy 10(4): 616-36. 
Harlow, C. and Rawlings, R. (2006) 'Promoting accountability in multi-level governance: a network approach', European Governance Papers, available at http://www.connexnetwork.org/eurogov/pdf/egp-connex-C-06-02.pdf (accessed 20 April 2012).

Heidbreder, E. (2011) 'Structuring the European administrative space: policy instruments of multi-level administration', Journal of European Public Policy 18(5): 636-53.

Heinelt, H. (2008) 'How to achieve governability in multi-level policymaking: lessons from the EU structural funds and EU environmental policy', in T. Conzelmann and R. Smith (eds), Multi-level Governance in the European Union: Taking Stock and Looking Ahead, Baden Baden: Nomos, pp. 53-69.

Heinelt, H. and Lang, A. (2011) 'Regional actor constellations in EU cohesion policy: differentiation along the policy cycle', Central European Journal of Public Policy 5(2): 4-29.

Hepburn, E. (2008) 'The rise and fall of a "European of the Regions", Regional and Federal Studies 18(5): 537-55.

Héritier, A. and Rhodes, M. (2011) New Modes of Governance in Europe: Governing in the Shadow of Hierarchy, Basingstoke: Palgrave Macmillan.

Hodson, D. and Maher, I. (2001) 'The open method as a new mode of governance: the case of soft economic policy coordination', Journal of Common Market Studies 39(4): 719-46.

Hooghe, L. (ed.) (1996) Cohesion Policy and European Integration: Building Multi-level Governance, Oxford: Clarendon Press.

Hooghe, L. and Marks, G. (2001) Multi-level Governance and European Integration, Lanham, MD: Rowman and Littlefield.

Hooghe, L. and Marks, G. (2003) 'Unraveling the central state, but how? Types of multi-level governance', American Political Science Review 97(2): 233-43.

Hooghe, L. and Marks, G. (2008) 'A postfunctionalist theory of European integration: from permissive consensus to constraining dissensus', British Journal of Political Science 39: 1-23.

Jessop, B. (2004) 'Multi-level governance and multi-level metagovernance', in I. Bache and M. Flinders (eds), Multi-level Governance, Oxford: Oxford University Press, pp. 49-74.

Jordan, A. (2001) 'The European Union: an evolving system of multi-level governance ... or government?' Policy and Politics 29(2): 193-208.

Jordan, A. and Schout, A. (2006) The Coordination of the European Union: Exploring the Capacities of Networked Governance, Oxford: Oxford University Press.

Juncos, A. and Pomorska, K. (2010) 'Secretariat, facilitator or policy entrepreneur? Role perceptions of officials of the Council Secretariat', EIoP, 14, Special Issue 1, available at http://eiop.or.at/eiop/index.php/eiop/article/view/2010_007a (accessed 10 February 2012).

Kaiser, R. and Prange, H. (2004) 'Managing diversity in a system of multi-level governance: the open method of co-ordination in innovation policy', Journal of European Public Policy 11(2): 249-66.

Kaul, I. (2010) 'The changing role of the United Nations: lessons for multi-level governance', in H. Enderlein, S. Wälti and M. Zürn (eds), Handbook on Multi-level Governance, Cheltenham: Edward Elgar, pp. 323-42.

Keating, M. and Loughlin, J. (1997) The Political Economy of Regionalism, London: Frank Cass.

Kern, K. and Bulkely, H. (2009) 'Cities, Europeanization and multi-level governance: governing climate change through transnational municipal networks', Journal of Common Market Studies 47(3): 309-332.

Knill, C. and Tosun, J. (2008) 'Emerging patterns of multi-level governance in EU Environmental Policy', in T. Conzelmann and R. Smith (eds), Multi-level Governance in the European Union: Taking Stock and Looking Ahead, Baden Baden: Nomos, pp. 145-62. 
Knodt, M. (2004) 'International embeddedness of European multi-level governance', Journal of European Public Policy 11(4): 701-19.

Kohler-Koch, B. (ed.) (2003) Linking EU and National Governance, Oxford: Oxford University Press.

Kohler-Koch, B. (2006) 'Research on EU governance: insight from a stock-taking exercise’, Connex Newsletter 3: 4-6.

Kohler-Koch, B. and Eising, R. (eds) (1999) The Transformation of Governance in the European Union, London: Routledge.

Kohler-Koch, B. and Larat, F. (eds) (2009) European Multi-level Governance: Contrasting Images in National Research, Cheltenham: Edward Elgar.

Levi-Faur, D. (ed.) (2012) Oxford Handbook of Governance, Oxford: Oxford University Press.

Littoz-Monnet, A. (2010) 'Dynamic multi-level governance - bringing the study of multi-level interactions into the theorising of European integration', EIoP 14(1), available at http://eiop.or.at/eiop/index.php/eiop/article/view/2010_001a (accessed 15 February 2012).

Marks, G. (1993) 'Structural policy and multi-level governance in the EC', in A. Cafruny and G. Rosenthal (eds), The State of the European Community: The Maastricht Debate and Beyond, Boulder, CO: Lynne Rienner, pp. 391-411.

Marks, G. (1996) 'An actor-centred approach to multi-level governance', Regional and Federal Studies 6(2): 20-38.

Marks, G. and Hooghe, L. (2004) 'Contrasting visions of multi-level governance', in I. Bache and M. Flinders (eds), Multi-level Governance, Oxford: Oxford University Press, pp. 15-30.

Marks, G., Hooghe, L. and Blank, K. (1996) 'European integration from the 1980s: state-centric v. multi-level governance', Journal of Common Market Studies 34(3): 341-78.

Milio, S. (2010) From Policy to Implementation in the European Union: The Challenge of a Multi-level Governance System, London: Tauris Academic.

Obydenkova, A. (2010) 'Multi-level governance in post-Soviet Eurasia: problems and promises', in H. Enderlein, S. Wälti and M. Zürn (eds), Handbook on Multi-level Governance, Cheltenham: Edward Elgar, pp. 292-307.

Olsson, J. (2003) 'Democracy paradoxes in multi-level governance: theorizing on structural fund system research', Journal of European Public Policy 10(2): 283-300.

Papadopoulos, Y. (2008) 'Problems of democratic accountability in network and multilevel governance', in T. Conzelmann and R. Smith (eds), Multi-level Governance in the European Union: Taking Stock and Looking Ahead, Baden Baden: Nomos, pp. 31-52.

Papadopoulos, Y. (2010) 'Accountability and multi-level governance: more accountability, less democracy?', West European Politics 33(5): 1030-49.

Paraskevopoulos, C. (2001) 'Social capital, learning and EU regional policy networks: evidence from Greece', Government and Opposition 36(2): 251-77.

Perraton, J. and Wells, P. (2004) 'Multi-level governance and economic policy', in I. Bache and M. Flinders (eds), Multi-level Governance, Oxford: Oxford University Press, pp. 179-94.

Peters, B. and Pierre, J. (2004) 'Multi-level governance and democracy: a Faustian bargain?' in I. Bache and M. Flinders (eds), Multi-level Governance, Oxford: Oxford University Press, pp. 75-89.

Piattoni, S. (2008) 'The development of the structural funds: a success story?', in T. Conzelmann and R. Smith (eds), Multi-level Governance in the European Union: Taking Stock and Looking Ahead, Baden Baden: Nomos, pp. 73-93.

Piattoni, S. (2009) 'Multi-level governance: a historical and conceptual analysis', Journal of European Public Policy 31(2): 163-80.

Pierson, P. (1996) 'The path to European integration - a historical institutional analysis', Comparative Political Studies 29(2): 123-62. 
Rosenau, J. (2004) 'Contrasting visions of multi-level governance', in I. Bache and M. Flinders (eds), Multi-level Governance, Oxford: Oxford University Press, pp. 31-48.

Sbragia, A. (2010) 'Multi-level governance and comparative regionalism', in H. Enderlein, S. Wälti and M. Zürn (eds), Handbook on Multi-level Governance, Cheltenham: Edward Elgar, p. 267-278.

Scharpf, F. (1997a) Games Real Actors Play: Actor-Centred Institutionalism in Policy Research, Boulder, CO: Westview Press.

Scharpf, F. (1997b) 'Introduction: the problem-solving capacity of multi-level governance', Journal of European Public Policy 4(4): 520-38.

Schout, A. (2009) 'Organizational learning in the EU's multi-level governance system', Journal of European Public Policy 16(8): 1124-44.

Schmitter, P. (2004) 'Neo-neofunctionalism', in A. Wiener and T. Diez (eds), European Integration Theory, Oxford: Oxford University Press, pp. 45-74.

Schmitter, P. and Kim, S. (2005) 'The experience of European integration and the potential for Northeast Asian integration', East-West Center Working Papers 10: 1-23, available at http://www.eastwestcenter.org/sites/default/files/private/PSwp010.pdf (accessed 10 September 2011).

Schreurs, M. (2010) 'Multi-level governance the ASEAN way', in H. Enderlein, S. Wälti and M. Zürn (eds), Handbook on Multi-level Governance, Cheltenham: Edward Elgar, pp. 308-20.

Slaughter, A.-M. and Hale, T. (2010) 'Transgovernmental networks and multi-level governance', in H. Enderlein, S. Wälti and M. Zürn (eds), Handbook on Multilevel Governance, Cheltenham: Edward Elgar, pp. 358-69.

Smith, M. (2004) 'Toward a theory of EU foreign policy-making: multilevel governance, domestic politics, and national adaptation to Europe's common foreign and security policy', Journal of European Public Policy 11(4): 740-58.

Spendzharova, A. (2011) 'Is more "Brussels" the solution? New European Union member states' preferences about the European financial architecture', Journal of Common Market Studies 50(2): 315-34.

Stubbs, P. (2005) 'Stretching concepts too far? Multi-level governance policy transfer and the politics of scale in South East Europe', Southeast European Politics 6(2): 66-87.

Taylor, A., Geddes, A. and Lees, C. (2012) The European Union and South East Europe - The Dynamics of Europeanization and Multilevel Governance, London: Routledge.

Thielemann, E. (1999) 'Institutional limits of a "Europe with the Regions": EC stateaid control meets German federalism', Journal of European Public Policy 6(3): 399-418.

Warleigh, A. (1999) The Committee of the Regions: Institutionalising Multi-level Governance? London: Kogan Page.

Warleigh-Lack, A. (2008) 'The EU, ASEAN and APEC in comparative perspective', in P. Murray (ed.), Europe and Asia: Regions in Flux, Basingstoke: Palgrave Macmillan, pp. 23-41.

Welch, S. and Kennedy-Pipe, C. (2004) 'Multi-level governance and International Relations', in I. Bache and M. Flinders (eds), Multi-level Governance, Oxford: Oxford University Press, pp. 127-144.

Zito, A. and Schout, A. (2009) 'Learning theory reconsidered: EU integration theories and learning', Journal of European Public Policy 16(8): 1103-23.

Zürn, M. (2012) 'Global governance as multi-level governance', in D. Levi-Faur (ed.), Oxford Handbook of Governance, Oxford: Oxford University Press, pp. 730-74. 